\title{
Peat Water Treatment with Natural Inorganic Coagulant
}

\author{
Ardiansyah $^{1}$, Syaiful Bahri ${ }^{2}$, Saryono $^{3}$, Wawan $^{4}$ \\ ${ }^{1}$ Student of Doctoral Program in Environmental Sciences, University of Riau \\ ${ }^{2}$ Faculty of Engineering, University of Riau \\ ${ }^{3}$ Faculty of Mathematics and Natural Sciences, University of Riau \\ ${ }^{4}$ Faculty of Agriculture, University of Riau
}

\begin{abstract}
Rapid of Indonesia population growth has an impact on increasing human needs, not least the need for water. Peat water treatment, in principle, is the process of purifiying of water compounds or substances dissolved and suspended in peat water, which were not expected to exist in water. In order of peat water to be used by community for drinking water, it is necessary to find, ways of peat water treatment easy and cheap. The natural resources that are available around us are always able to provide a valuable contribution to humans if managed properly. The use of natural inorganic materials is one solution to be taken in peat water treatment, one to its. Effective contact time of natural materials as a coagulant to pH, TDS (Total Disolved Solid), and the color of peat water respectively. The results showed that natural inorganic coagulant dosage formulation, $\mathrm{A}_{14}$ (clay $10 \mathrm{~g}, 0.25 \mathrm{~g} \mathrm{NaHCO}$ and $1.0 \mathrm{~g} \mathrm{PAC}$ ) for the 15-minute observation time, the most effective because it increase the $\mathrm{pH}$ value of peat from 4 to 7 , 08 , to reduce color levels of peat water of $25 \mathrm{TCU}$ to 0.00 , but it on the other side has not been able to improve the quality of the water TDS peat from the initial state is $87 \mathrm{mg} / \mathrm{l}$. As a result it has met the standards Regulation of the Minister of Health Number. 492 / Menkes / Per / IV / 2010 for Drinking Water Quality Requirements.
\end{abstract}

Keywords: natural coagulant, formulations, peat water, coagulant

\section{Introduction}

The rapid population growth has an impact on increasing human needs. One solution that can be taken is to exploit the potential of water available in nature, in this case the peat water. Peat water generally have a poorer quality, because it has a blackish brown color, low $\mathrm{pH}$, acid taste and contain other ingredients, so it is necessary to do processing first to become eligible to use and meet the standards of Regulation of the Minister of Health Number. 492 / Menkes / Per / IV / 2010 on Drinking Water Quality Requirements.

Peat water treatment, in principle, is the process of splitting water of compounds or substances dissolved and suspended in water, which is not expected to exist in the water, such as color, smell, taste and other substances that can harm human health when consumed water, In order peat water can be used by communities for drinking water, is necessary to find ways of peat water treatment simple and inexpensive. One alternative is the use of locally available natural coagulant which can be obtained around us [1]. Inorganic natural resources that surround us can always provide a valuable contribution to humans if managed properly. One pengohan process raw water into potable water is a coagulationflocculation process. The process is the addition of a chemical compound which is to form floc particles that are difficult or combine with other particles settle so has the speed settle faster. Floc formed should be removed by means of sedimentation [2].

Various studies on the use of natural inorganic coagulants such studies have been carried [3], using Poly Aluminum Chloride (PAC) and aluminum sulfate in reducing water turbidity peat. Other investigators have reported that the liquid coagulant Cengar clay can be used to improve the characteristics of the peat water [4], a decrease in Fe and $\mathrm{Mn}$ ions groundwater using clay peat [5].

\section{Research Methods}

Sampling sites in this study conducted in Meranti Islands regency, Riau Province, Indonesia. Selanjtnyadilakukan research at the Laboratory of the University of Riau.

\subsection{Tools and Materials}

The tools will be used in this study is a $\mathrm{pH}$ meter, turbidimeter, T70 Spectrometer UV / VIS, TDS meter, measuring cups, paper filter and an analytical balance. The materials used in this study is peat water, PAC (poly aluminum cloride), $\mathrm{NaHCO} 3$, and Klei sites.

\subsection{Methods}

This research was conducted to find the dosage formulation and effective contact time in the use of natural materials as the inorganic coagulant to water turf. The method used in this research is the experimental method.

\section{Research Procedure}

\subsection{Preparation Materials Coagulants}

The procedure begins with eroded soil research clay, smooth and then do the heating in the oven, with a temperature of \pm 


\section{International Journal of Science and Research (IJSR) \\ ISSN (Online): 2319-7064}

Index Copernicus Value (2013): 6.14 | Impact Factor (2015): 6.391

$110{ }^{\circ} \mathrm{C}$ and more or less for $\pm 1 \times 24$ hours. Heating aims to separate the soil clay with other deposits carried away when making such clay.

Clay preheated then introduced into distilled water and stirred, then allowed a few minutes to settle. The precipitate is what is the pure clay and will be used as a coagulant.

\subsection{Preparation Variation Variation Formulation and Contacts Time Coagulant}

Variations coagulant formulations used in this study consisted of clay research sites (Meranti Islands District), $\mathrm{NaHCO}_{3}$ and PAC (Poly Aluminium Chloride). The detailed formulation of natural inorganic coagulants in this study is presented in Table 1.

Table 1: Dose Formulation coagulant Inorganic time Contacts 5, 10 and 15 minutes

\begin{tabular}{|c|c|c|c|}
\hline \multirow{2}{*}{ Kode } & \multicolumn{3}{|c|}{ Formulations } \\
\cline { 2 - 4 } & Clay $(\mathrm{g})$ & $\mathrm{NaHCO}_{3}(\mathrm{~g})$ & PAC $(\mathrm{g})$ \\
\hline $\mathrm{A}_{1}$ & 5 & 0,25 & 0,5 \\
\hline $\mathrm{A}_{2}$ & 5 & 0,5 & 0,5 \\
\hline $\mathrm{A}_{3}$ & 5 & 0,75 & 0,5 \\
\hline $\mathrm{A}_{4}$ & 10 & 0,25 & 0,5 \\
\hline $\mathrm{A}_{5}$ & 10 & 0,5 & 0,5 \\
\hline $\mathrm{A}_{6}$ & 10 & 0,75 & 0,5 \\
\hline $\mathrm{A}_{7}$ & 15 & 0,25 & 0,5 \\
\hline $\mathrm{A}_{8}$ & 15 & 0,5 & 0,5 \\
\hline $\mathrm{A}_{9}$ & 15 & 0,75 & 0,5 \\
\hline $\mathrm{A}_{10}$ & 5 & 0,25 & 1,0 \\
\hline $\mathrm{A}_{11}$ & 5 & 0,5 & 1,0 \\
\hline $\mathrm{A}_{12}$ & 5 & 0,75 & 1,0 \\
\hline $\mathrm{A}_{13}$ & 10 & 0,25 & 1,0 \\
\hline $\mathrm{A}_{14}$ & 10 & 0,5 & 1,0 \\
\hline $\mathrm{A}_{15}$ & 10 & 0,75 & 1,0 \\
\hline $\mathrm{A}_{16}$ & 15 & 0,25 & 1,0 \\
\hline $\mathrm{A}_{17}$ & 15 & 0,5 & 1,0 \\
\hline $\mathrm{A}_{18}$ & 15 & 0,75 & 1,0 \\
\hline $\mathrm{A}_{19}$ & 5 & 0,25 & 1,5 \\
\hline $\mathrm{A}_{20}$ & 5 & 0,5 & 1,5 \\
\hline $\mathrm{A}_{21}$ & 5 & 0,75 & 1,5 \\
\hline $\mathrm{A}_{22}$ & 10 & 0,25 & 1,5 \\
\hline $\mathrm{A}_{23}$ & 10 & 0,5 & 1,5 \\
\hline $\mathrm{A}_{24}$ & 10 & 0,75 & 1,5 \\
\hline $\mathrm{A}_{25}$ & 15 & 0,25 & 1,5 \\
\hline $\mathrm{A}_{26}$ & 15 & 0,5 & 1,5 \\
\hline $\mathrm{A}_{27}$ & 15 & 0,75 & 1,5 \\
\hline & & & \\
\hline & & & \\
\hline
\end{tabular}

\section{Results}

\subsection{The degree of acidity (pH)}

\section{a. Effect of dose clay versus $\mathrm{pH}$ of peat water}

Clay doses influence on $\mathrm{pH}$ can be seen in Figure 1. The graph formulation dose is clay $5 \mathrm{ml}\left(\mathrm{A}_{1}\right), 10 \mathrm{ml}\left(\mathrm{A}_{4}\right), 15 \mathrm{ml}$ $\left(\mathrm{A}_{7}\right), 0.5 \mathrm{~g} \mathrm{PAC}$, and $0.25 \mathrm{~g} \mathrm{NaHCO}_{3}$.

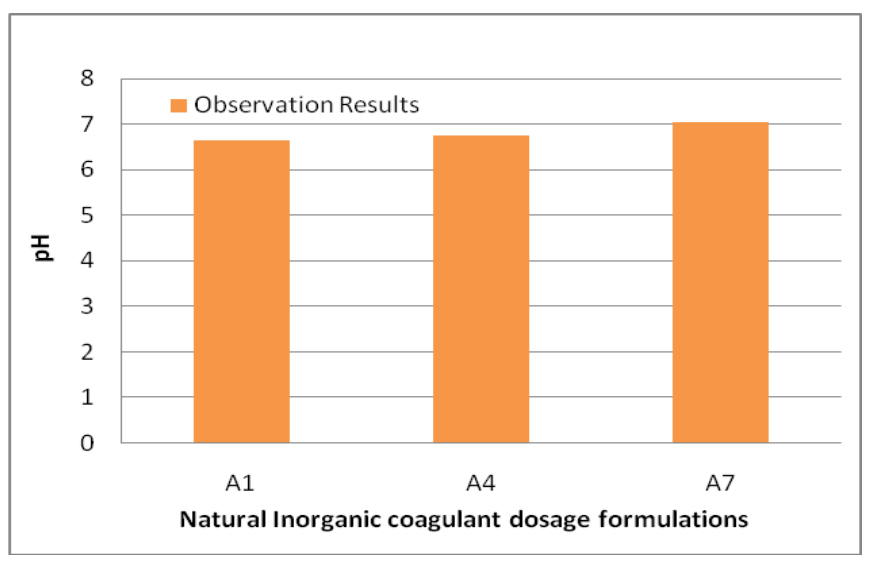

Figure 1: The effect clay dose on $\mathrm{pH}$

Based on the graph above, an increase in the $\mathrm{pH}$ of peat water along with increased coagulant dosage. This happens because of increasing doses caused an increase in the ability clay are in the process of coagulation and flocculation. Can also occur due to attractive forces charged ions and bind to each other to form neutral particles. This leads to the reduction in the number of $\mathrm{H}^{+}$ions, which means less acidic conditions in the water anyway. The increase in the degree of acidity $(\mathrm{pH})$.

In line with the research [4], which through the process of coagulation and flocculation, organic acid peat initially dispersed in water can be precipitated and separated. If the amount of organic acid decreases the $\mathrm{pH}$ of the the peat water will be increased. In line with the research [6], where the higher the dose of coagulant can lead to an increase in the $\mathrm{pH}$ value of peat.

\section{b. Effect of NaHCO3 dose on pH of peat water}

Effect of dose $\mathrm{NaHCO}_{3}$ to $\mathrm{pH}$ peat water can be seen in Figure 2. Dose formulations on the graph is clay $5 \mathrm{ml}, 1.0 \mathrm{~g}$ PAC, and $\mathrm{NaHCO}_{3}$ was $0.25 \mathrm{~g}\left(\mathrm{~A}_{10}\right), 0.5 \mathrm{~g}\left(\mathrm{~A}_{11}\right)$ and $0.75 \mathrm{~g}$ $\left(\mathrm{A}_{12}\right)$.

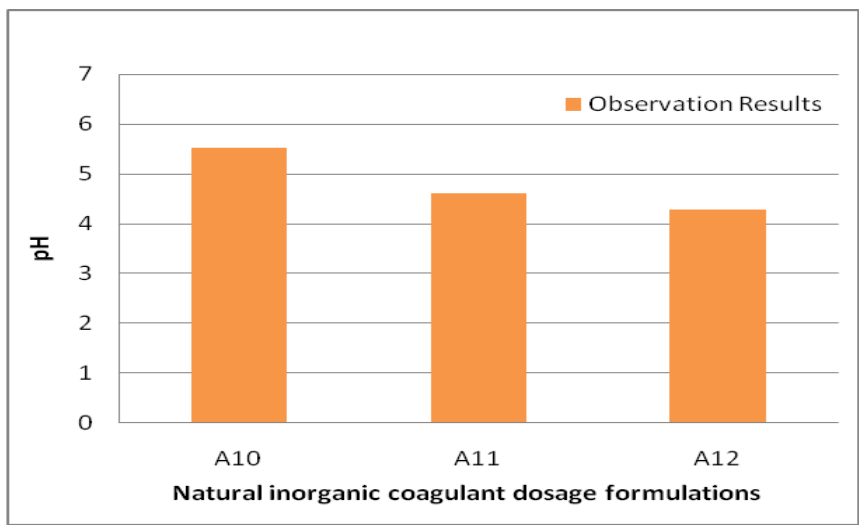

Figure 2: The effect dose $\mathrm{NaHCO}_{3}$ on the $\mathrm{pH}$

The graphic above, decreased $\mathrm{pH}$ peat water with increasing doses of $\mathrm{NaHCO}_{3}$. This happens because they influence the relationship between clay, $\mathrm{NaHCO}_{3}$, or PAC, so that each of the constituents of this formulation have an effect on the measured parameters. A decrease in $\mathrm{pH}$ caused by excess coagulant dosage formulation, in this case the optimum condition is achieved at a volume of $0.25 \mathrm{~g} \mathrm{NaHCO}_{3}$, thus 


\section{International Journal of Science and Research (IJSR) \\ ISSN (Online): 2319-7064 \\ Index Copernicus Value (2013): 6.14 | Impact Factor (2015): 6.391}

increasing the volume of $\mathrm{NaHCO}_{3}$ impact on improving the process of hydrolysis in water.

In contrast to the results of research and [7], where the results of the study showed that the higher the concentration of $\mathrm{NaHCO}_{3}$ is used, the degree of acidity $(\mathrm{pH})$ tend to be higher. This increase is due to the properties $\mathrm{NaHCO}_{3}$ buffer $(\mathrm{pH}$ guard). $\mathrm{NaHCO}_{3}$ and the reaction of the acid resulting in a salt and carbonic acid, which is easily decomposed into carbon dioxide and water [8].

\section{c. Effect of PAC dose on $\mathrm{pH}$ of peat water}

PAC dosage influence on the $\mathrm{pH}$ of the peat water can be seen in Figure 3. Formulation dose on the graph is the study site clay $5 \mathrm{ml}, 0.5 \mathrm{~g}$ PAC $\left(\mathrm{A}_{1}\right), 1.0 \mathrm{~g}\left(\mathrm{~A}_{10}\right), 1.5 \mathrm{~g}\left(\mathrm{~A}_{19}\right)$ and $\mathrm{NaHCO}_{3}$ was $0.25 \mathrm{~g}$.

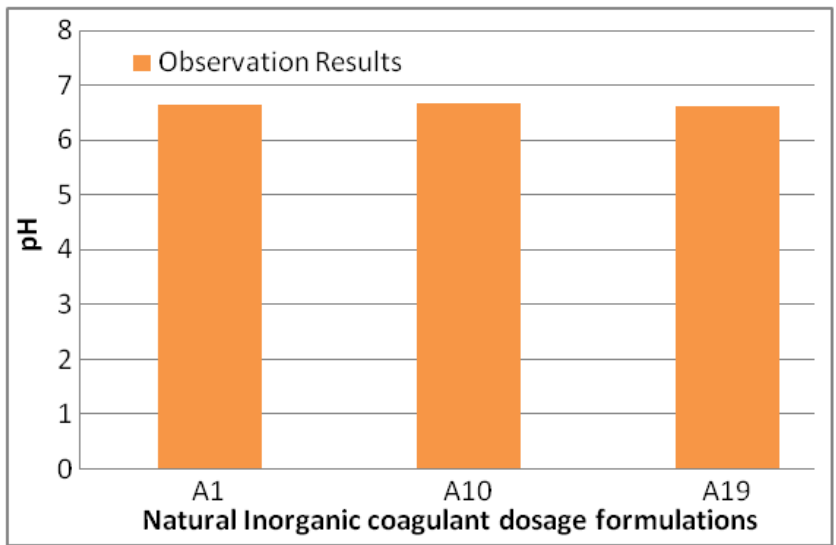

Figure 3: The effect dose $\mathrm{PAC}$ on the $\mathrm{pH}$

The above graph shows an increase in the dose of PAC no effect on increasing $\mathrm{pH}$ peat water. $\mathrm{PAC}$ is an effective coagulant used in color and TDS reduction in water, but not a great influence on the $\mathrm{pH}$ of the water. In line with [9], that the PAC is most common in the water treatment $\mathrm{Al}_{12} \mathrm{Cl}_{12}$ $(\mathrm{OH})_{24}$. PAC can be used as a coagulant for coagulation has strong capability, can work effectively on a wide $\mathrm{pH}$ range, the cost is cheap and easy way of operation but has little effect on the $\mathrm{pH}$.

This is different to [10] of which more and more doses of solid PAC is added to the raw water, then increasing the $\mathrm{pH}$ value of the raw water up to 7.30.

\section{d. Effect of contact time on the $\mathrm{pH}$ peat water}

Effect of contact time on the water's $\mathrm{pH}$ peat can be seen in Figure 3 . The graphs above, has a coagulant formulation that clay $10 \mathrm{ml}, 0.25 \mathrm{~g} \mathrm{NaHCO}_{3}$ and $0.5 \mathrm{~g}$ PAC.

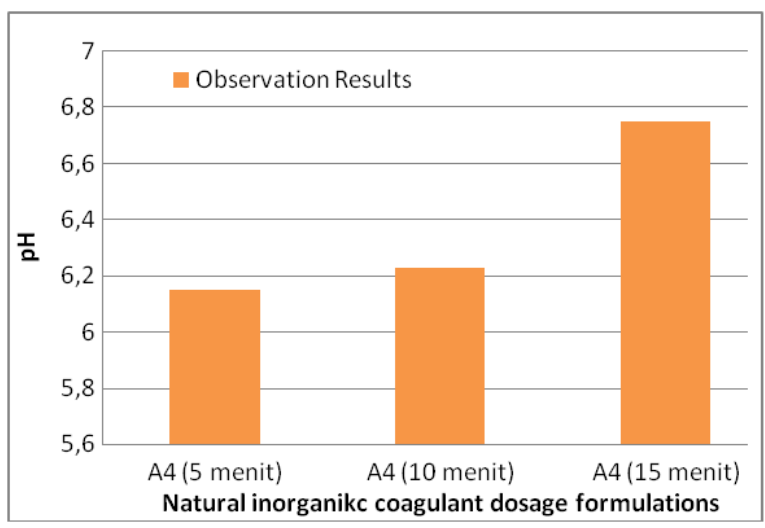

Figure 4: The effect variation of contact time on the $\mathrm{pH}$

The graph above shows that an increase in the $\mathrm{pH}$ of peat water along with increasing contact time. This happens because the longer the contact time, the more the process of hydrolysis in water so that the ions $\mathrm{H}^{+}$ionized water so that it will be greater the lower the $\mathrm{pH}$ value (acid). This is in line with the opinion of [11], which states that the longer the contact time, the $\mathrm{pH}$ of the water will increase.

\subsection{Total Dissolved Solid (TDS)}

\section{a. Effect of dose clay versus TDS of peat water}

Effect of dose clay research sites against TDS peat water, presented in Figure 5. The formulation of the dose on the graph is clay $5 \mathrm{ml}$ (A1), $10 \mathrm{ml}$ (A4) and $15 \mathrm{ml}$ (A7), $0.5 \mathrm{~g}$ $\mathrm{PAC}$, and $\mathrm{NaHCO}_{3} 0,25 \mathrm{~g}$.

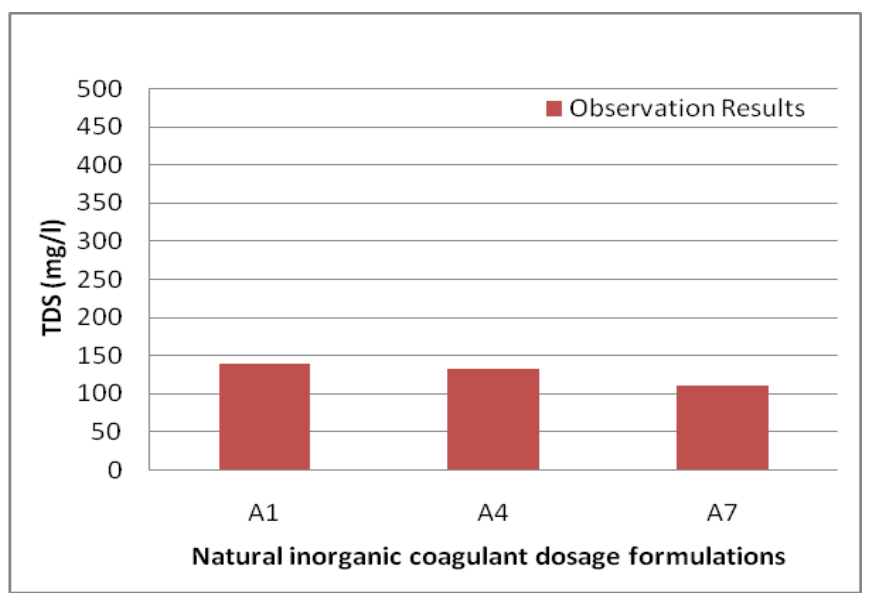

Figure 5: The effect dose clay on TDS

Based on the graph above, it can be seen that an increase in water TDS peat as clay dose escalation study sites. This is due to increased clay doses can cause an increase in dissolved minerals contained in the peat water. In optimum conditions the coagulation process can both reduce levels of TDS in water, because the ingredients are dissolved in the peat water can form floc and then tersedimentasi by the influence of gravity.

In line with the opinion of [12], which states that at concentrations exceeding the optimum dose of turbidity back riding as colloidal neutralized everything and settles at a concentration of coagulant optimum, so that the excess coagulant will cause turbidity because it does not interact with the colloidal particles other different charge. So also 


\section{International Journal of Science and Research (IJSR) \\ ISSN (Online): 2319-7064 \\ Index Copernicus Value (2013): 6.14 | Impact Factor (2015): 6.391}

with the results of the study [11], which showed that the higher the concentration of coagulant, causing the lower the TDS reduction percentage. Likewise with [4].

\section{b. Effect of $\mathrm{NaHCO}_{3}$ dose on TDS of peat water}

Effect of $\mathrm{NaHCO}_{3}$ dose to TDS peat water, presented in Figure 6 . The formulation dosage on above is clay research sites $5 \mathrm{ml}, 1.0 \mathrm{~g} \mathrm{PAC}$, and $\mathrm{NaHCO}_{3}$ was $0.25 \mathrm{~g}\left(\mathrm{~A}_{10}\right), 0.5 \mathrm{~g}$ $\left(\mathrm{A}_{11}\right)$ and $0.75 \mathrm{~g}\left(\mathrm{~A}_{12}\right)$.

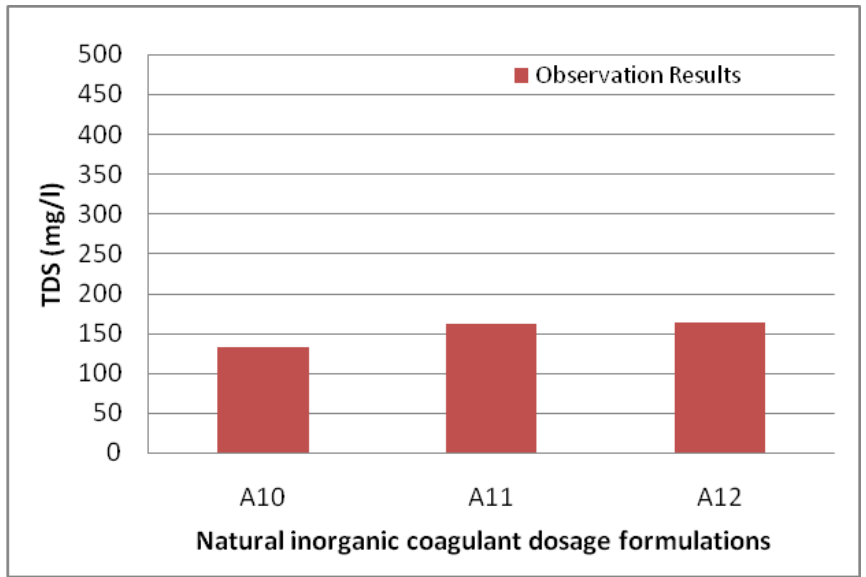

Figure 6: The effect dose $\mathrm{NaHCO}_{3}$ on TDS

Increasing doses of $\mathrm{NaHCO}_{3}$ impact on improving TDS peat water. $\mathrm{NaHCO}_{3}$ dose of $0.25 \mathrm{~g}$ is the optimum dose in the process of coagulation in this study, so that at the dose of peat water TDS has decreased significantly from the initial TDS is $87 \mathrm{mg} / 1$.

Extra doses causes the optimum conditions are exceeded, so that TDS back up. This is in accordance with the opinion of [10], which states that if the coagulant dosage is too much or too little, the turbidity will rise again. It must therefore be sought point most optimum coagulant dose that water quality will be better.

\section{c. Effect of PAC dosage on TDS of peat water}

Effect of PAC dosage to TDS water peat in this study is presented in Figure 7. The formulation dose in chart 1 above is clay research sites $5 \mathrm{ml}, 0.5 \mathrm{~g} \operatorname{PAC}\left(\mathrm{A}_{1}\right), 1.0\left(\mathrm{~A}_{10}\right), 1.5\left(\mathrm{~A}_{19}\right.$ ) and $\mathrm{NaHCO}_{3}$ was $0.25 \mathrm{~g}$.

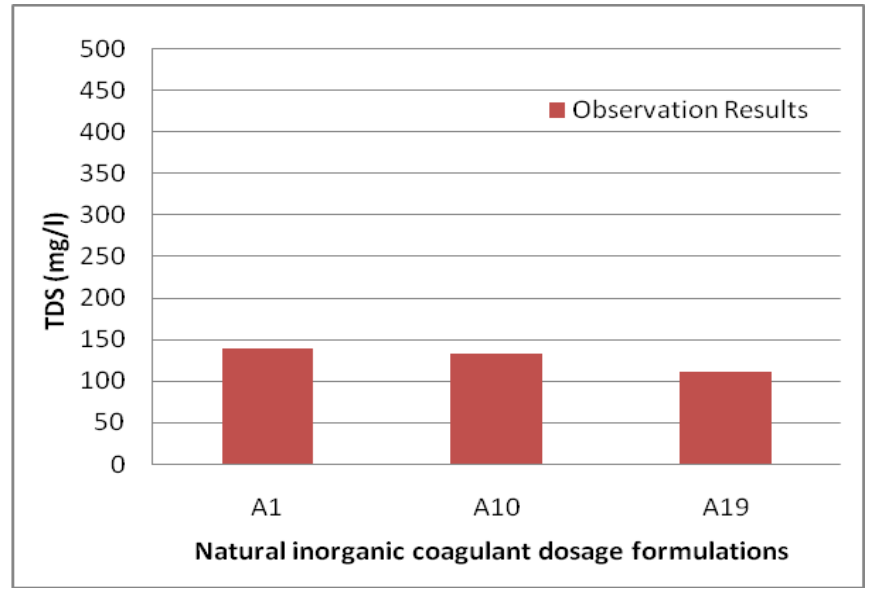

Figure 7: The effect dose PAC on TDS
Based on the graph above, it can be seen that the higher the dose of PAC, the lower the water TDS peat. This shows that the optimum condition can be achieved on the PAC maximum dose of $1.5 \mathrm{~g}$, in other words that the optimum conditions of coagulation and flocculation process goes well and the balance between the needs of coagulant with organic ingredients and minerals to be flocculated and deposited by gravity.

In line with [13], the said that the charge of the particle by neutralizing the coagulant is only possible if the particle charge has a concentration that is strong enough to hold the attractive forces between colloidal particles. Similarly [14] states that the PAC carry out a flock caused active group work effectively bind colloidal alumina reinforced polymer chains of the polyelectrolyte groups so that clots floknya becomes denser.

\section{d. Effect of contact time on the TDS peat water}

Effect of contact time on the water TDS peat in this study is presented in Figure 8. The formulation of the dose on the graph is clay research sites $10 \mathrm{~g}, 0.5 \mathrm{~g} \mathrm{PAC}$, and $\mathrm{NaHCO}_{3}$ was $0.25 \mathrm{~g}$.



Figure 8: The effect of contact time of the TDS

Based on the graph above, it appears that an increase in water TDS peat along with an increase in contact time which occurs due to the optimum contact time has elapsed, so that the coagulation and flocculation process has been completed the case and the particle colloidal charged had become neutral. Excess contact time cause TDS go up, because the compounds that have undergone the process of ionization in the water can not bind again form a bond [11] .

The formation of positive and negative ions are also produced from the decomposition of coagulant, which can then neutralize the charge of the colloids and particles bind to form a floc or blob [15].

\subsection{Color}

\section{a. The influence of dose clay on color of peat water}

The influence of the location clay dose study of peat water color can be seen in Figure 9. The formulation of the dose on the graph is clay $5 \mathrm{ml}(\mathrm{A} 1), 10 \mathrm{ml}$ (A4) and $15 \mathrm{ml}$ (A7), $0.5 \mathrm{~g}$ $\mathrm{PAC}$, and $\mathrm{NaHCO}_{3} 0,25 \mathrm{~g}$. 


\section{International Journal of Science and Research (IJSR) \\ ISSN (Online): 2319-7064}

Index Copernicus Value (2013): 6.14 | Impact Factor (2015): 6.391

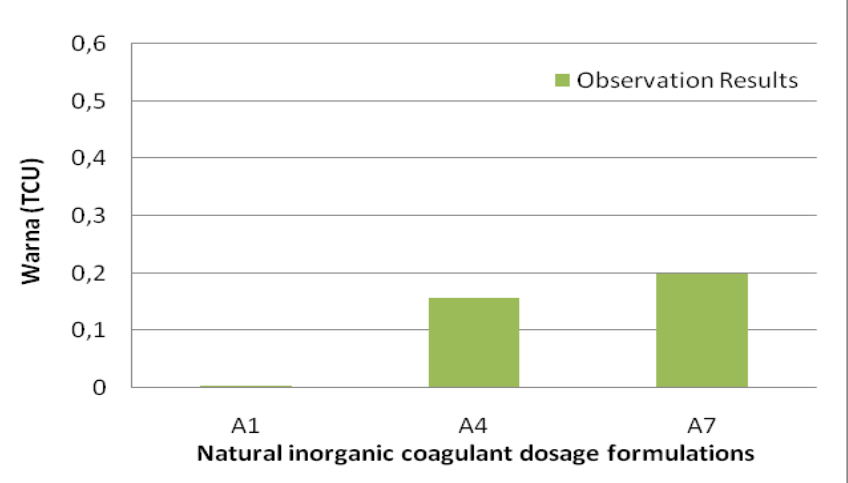

Figure 9: The effect dose clay on color

Based on the graph above, it appears that there is a decrease in water color of peat, along with increased doses of Klei sites. The formation of positive and negative ions are also produced from the decomposition of coagulant, which can then neutralize the charge of the colloids and particles bind to form a floc or blob [15]. The formation of floc or the lump peat menyababkan water is becoming increasingly clear, because the substances are abused causes water color peat clots and further precipitate.

In line with [11], where there are fluctuations in water color of peat at each dose Klei. This is according to [16], the addition of excessive dosage will make colloidal form has become stable again because of the lack of space to set up a liaison particles so that color will increase again.

\section{b. Effect of dose $\mathrm{NaHCO}_{3}$ on the color on peat water}

Effect of $\mathrm{NaHCO} 3$ dose of the peat water colors, presented in Figure 8. The formulation of the dose on the graph is the study site clay $5 \mathrm{ml}, 1.0 \mathrm{~g} \mathrm{PAC}$, and $\mathrm{NaHCO}_{3}$ was $0.25 \mathrm{~g}$ (A10), $0.5 \mathrm{~g}$ (A11) and $0.75 \mathrm{~g}$ (A12).

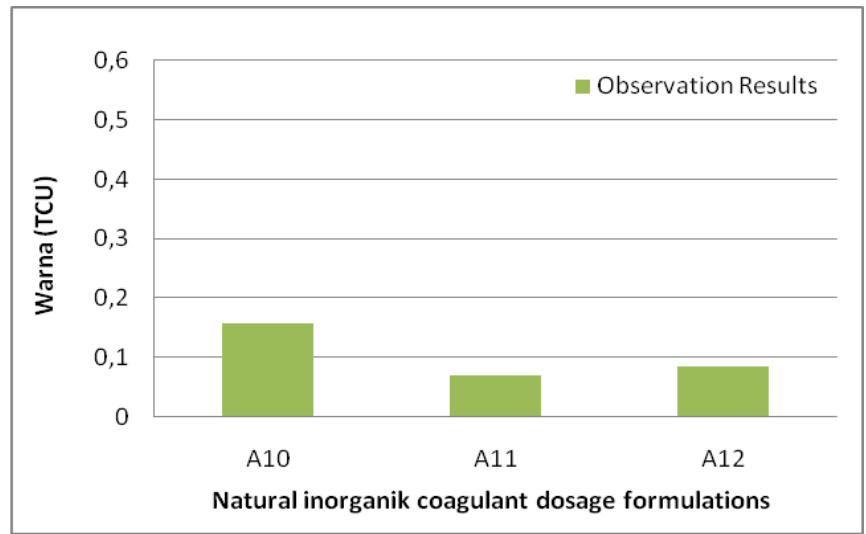

Figure 10: The effect dose $\mathrm{NaHCO}_{3}$ on color

The graph shows that the general decline in color intensity of peat water, along with increased doses of $\mathrm{NaHCO}$. This is due to the influence of $\mathrm{pH}$ in the process of reaction between water peat invitation coagulant meyababkan the process of coagulation and flocculation. In line with the opinion [3], which states that the peat water has a natural color containing colloidal particles are positively charged organic can not be deposited by gravity so it should be added the forces that the particles can be deposited. c. Effect of dose PAC on the color of the peat water

Effect of PAC on peat water color can be seen in Figure 11: Formulation dose in chart 1 above is clay research sites $5 \mathrm{ml}$, 0.5 g PAC (A1), 1.0 (A10), 1.5 (A19) and $\mathrm{NaHCO} 3$ was $0.25 \mathrm{~g}$.



Figure 11: The effect dose PAC on color

Based on the graph above, it appears that the decline in water the color of peat significantly from the original color of 25 TCU. However, the higher dose of PAC given, the more visible color enhancement peat water. In this study the optimum conditions of peat water color is achieved is 0,000 $\mathrm{TCU}$, the formulation of a natural coagulant anorgani Klei $10,0.25 \mathrm{~g} \mathrm{NaHCO}_{3}$ and $1.0 \mathrm{~g} \mathrm{PAC}$.

In accordance with the following statement, that the PAC is more effective in lowering levels of color due to the positive charge, PAC put into the water causing neutralization and adsorption processes patikel color in the water exceeds other coagulant types [17]. Likewise, according to [2], stated that the success of the allowance is determined by the color of the collision process between colloidal particles have been coagulated, so as to form a floc particles that are larger in size and compact, making it easy deposited.

\section{d. Effect of contact time on the color peat water}

Effect of contact time on the water color of peat can be seen in Figure 4.12. Dose formulations on the graph is Klei research sites $10 \mathrm{~g}, 0.5 \mathrm{~g} \mathrm{PAC}$, and $\mathrm{NaHCO}_{3}$ was $0.25 \mathrm{~g}$.

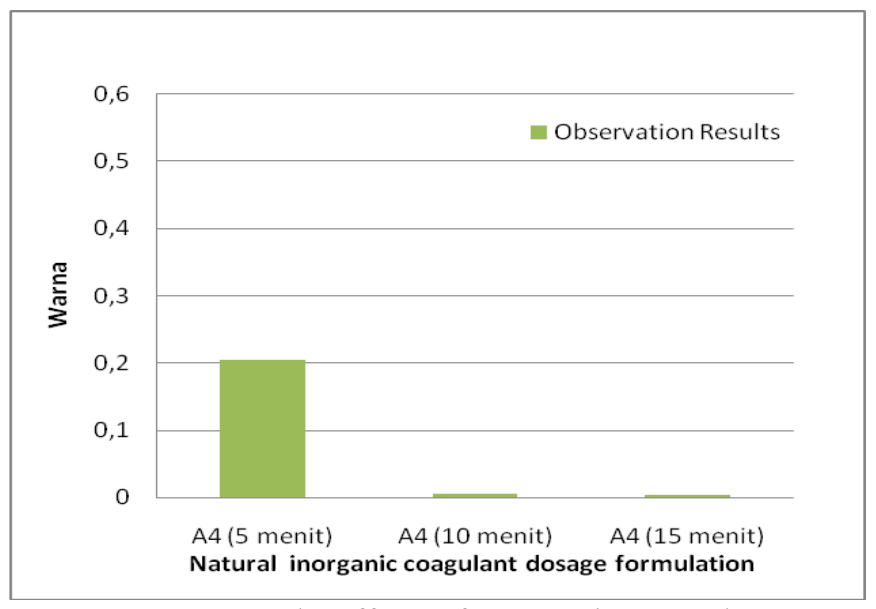

Figure 12: The effects of contact time to color 


\section{International Journal of Science and Research (IJSR) \\ ISSN (Online): 2319-7064}

Index Copernicus Value (2013): 6.14 | Impact Factor (2015): 6.391

Based on the graph above, it appears that the longer the contact time, the lower the water the color of peat. This is in line [11], because the contact time is longer floc-floc causes of color formed by coagulation-flocculation more that settles to the bottom due to gravity. In line with the [1], where the results of the study showed that a decline in water color of peat, along with increased contact time.

\section{Conclusion}

In the determination of inorganic natural coagulant dosage formulation, formulation A14 (clay $10 \mathrm{~g}, 0.25 \mathrm{~g} \mathrm{NaHCO} 3$ and $1.0 \mathrm{~g}$ PAC) for the 15-minute observation time, the formulation of the most effective because it can increase the $\mathrm{pH}$ value of peat from 4 to 7.08 , lowering the water color of peat $99.99 \%$, but has not been able to improve the quality of the TDS peat water.

\section{Recommendation}

Need deepening of this study was primarily on the effect of coagulant dosage formulations of the TDS, thereby obtained a lower number of achievements in this study.

\section{References}

[1] Irianty, RS. 2010. Pengaruh Massa Biji Kelor (Moringa oleifera Lamk) Dan Waktu Pengendapan Pada Pengolahan Air Gambut. Jurnal Sains dan Teknologi, Vol 9 No 2, September 2010 : 82-86.

[2] Amir, R., Isnaniawardhana, J.N. 2008. Penentuan Dosis Optimum Aluminium Sulfat dalam Pengolahan Air Sungai Cileueur Kota Ciamis dan Pemanfatan Resirkulasi Lumpur dengan Parameter pH, Warna, Kekeruhan, dan TSS. Jurnal Program Studi Teknik Lingkungan,Fakultas Teknik Sipil dan Lingkungan Institut Teknologi Bandung.

[3] Sutapa, I.D.A. 2014. Perbandingan Efesiensi Koagulan Poly Alimunium Chloride (PAC) dan Alumunium Sulfat dalam Menurunkan Turbiditas Air Gambut Dari Kabupaten Katingan Propinsi Kalimantan Tengah. Jurnal RISET Geologi dan Pertambangan, Vol 24 No 1, Juni 2014, 13-21. ISSN 0125-9849, e-ISSN 2354-6638. Pusat Penelitian Geoteknologi Lembaga Ilmu Pengetahuan Indonesia.

[4] Sutrisno, H., Muhdarina, T., Amri, A. 2014. Pengolahan Air Gambut dengan Koagulan Cair Hasil Ekstraksi Lempung Alam Desa Canger Menggunakan Larutan $\mathrm{H}_{2} \mathrm{SO}_{4}$. Jurnal Vol 1 No 2 Oktober 2014. FMIPA UNRI Pekanbaru.

[5] Agus, F., Subiksa, I.G.M. 2008. Lahan Gambut : Potensi Untuk Pertaian dan Aspek Lingkungan. Balai Penelitian Tanah Badan Penelitian dan Pengembangan Pertanian, IPB Bogor.

[6] Syahroni, R., Muhdarina., Linggawati, A. 2014. Pengolahan Air Gambut Menggunakan Koagulan Cair dari Lempung Aalam Cengar. JOM FMIPA Vol 1 No.2 Oktober 2014.
[7] Irzam, F, N dan Harijono. 2014. Pengaruh Penggantian Air dan Penggunaan $\mathrm{NaHCO}_{3}$ dalam Perendaman Ubi Kayu Iris (Manihot esculenta Crantz)Terhadap Kadar Sianida Pada Pengolahan Tepung Ubi Kayu. Jurnal Pangan dan Agroindustri Vol. 2 No 4 p.188-199.

[8] Kuncoro, P. R. 2009. Pemanfaatan Natrium Bikarbonat (Soda Kue) dan Asam Asetat (Cuka) Sebagai Propelan. Fakultas Matematika dan Ilmu Pengetahuan Alam.Universitas Sebelas Maret. Surakarta.

[9] Marieanna, Kristijarti A. Prima dan Suharto I. 2013. Penentuan Jenis Koagulan dan Dosis Optimum untuk Meningkatkan Efisiensi Sedimentasi dalam Instalasi Pengolahan Air Limbah Pabrik Jamu X. Lembaga Penelitian danPengabdian kepada Masyarakat : Universitas Parahyangan.

[10] Margaretha., Mayasari, R., Syaiful. 2012. Pengaruh Kualitas Air Baku Terhadap Dosis Dan Biaya Koagulan Aluminium Sulfat Dan Poly Aluminium Chloride. Jurnal Teknik Kimia Vol 18 No 4.

[11] Rusdi., Sidi, P.T.B, Pratama, R. 2014. Pengaruh Konsentrasi dan Waktu Pengendapan Biji Kelor Terhadap pH, Kekeruhan dan Warna Air Waduk Krenceng. Jurnal Integrasi Proses, Vol 5 No 1 Desember 2014 : 46 - 50.

[12] Yuliastri., Indra, R. 2010. Penggunaan Serbuk Biji Kelor (Moringa Oleifera) sebagai Koagulan dan Floakulan dalam Perbaikan Kualitas Air Limbah dan Air Tanah, Progam Studi Kimia Fakultas Sains dan Teknologi UIN. Syarif Hidayatullah, Jakarta.

[13] Kasmono, 2007. Efektivitas PAC dan Tawas dalam menurunkan warna air gambut di Singkawang, Kalimantan Barat. Universitas Diponegoro, Semarang.

[14] Pararaja, Arifin. 2008. Surfaktan. http://smk3ae.wordpress.com 2008/05/28/surfaktant-assabun-dan-detergent/ Tanggal Akses: 27/03/2016.

[15] Haines, M.G., 2003. Impact of Dual Alum and Polyaluminum Chloride Coagulation on Filtration. Master's Thesis. ColoradoState University. Colorado, 82pp.

[16] Yuliati, S. 2006. Proses Koagulasi-Flokulasi pada Pengolahan Tersier Limbah Cair PT Capsugel Indonesia. Fakultas Teknologi Pertanian Institut Pertanian Bogor

[17] Ramadhani, S., Sutanhaji, A.T., Widiatmono, B.R. 2013. Perbandingan Efektivitas Tepung Biji Kelor (Moringa oleifera Lamk), Poly Aluminium Chloride (PAC), dan Tawas sebagai Koagulan untuk Air Jernih. Jurnal Keteknikan Pertanian Tropis dan Biosistem, Vol 1 No 3 Oktober 2013,186-193.

\section{Author Profile}

Ardiansyah degrees S, Pi and M.M. He finished his Bachelor study Fishery (S1) in 2002 at the Faculty of Fisheries and Marine Sciences University of Riau. Continue the study Master in Management (S2) at the University of Muhammadiyah Jakarta in 2009 and was completed in 2011. Starting out in 2012, until today still continue the study in the Doctoral Program in Environmental Science Study Program in Environmental Sciences University of Riau. Working at the Department of Marine and Fisheries, Meranti Islands regency, Riau province, Indonesia. 